\title{
Pathological Laughter Following Intravenous Sodium Valproate
}

\author{
P.C. Jacob and R. Pratap Chand
}

\begin{abstract}
Background: Pathological laughter can be a sign of epilepsy, psychiatric illness, effect of toxins or psychotropic drugs or of structural brain disease. Method: Case Studies. Result: Two patients developed inappropriate uncontrollable laughter following intravenous sodium valproate for treatment of epilepsy. Conclusion: Pathological laughter can be a side effect of intravenous sodium valproate.
\end{abstract}

\begin{abstract}
RÉSUMÉ: La rire pathologique suite à l'administration intraveineuse de valpmate sodique. Introduction: Le rire pathologique peut être un signe d'épilepsie, de maladie psychiatrique, de l'effet de toxines ou de drogues psychotropes ou d'une maladie structurale du cerveau. Méthode: Histoires de cas. Résultat: Deux patients ont développé un rire incontrôlable, inapproprié, suite à l'administration intraveineuse de valproate sodique comme traitement de l'épilepsie. Conclusion: Le rire pathologique peut être un effet secondaire de l'administration intraveineuse de valproate sodique.
\end{abstract}

Can. J. Neurol. Sci. 1998; 25: 252-253

Sodium valproate (SVA) is a first line antiepileptic drug for absence, myoclonic and tonic-clonic seizures. During the past decade an intravenous formulation of SVA has become commercially available and its safety established. ${ }^{\prime}$ Pathological laughter (PL) is laughter that is inappropriate, unrestrained, uncontrollable or dissociated from any stimulus. ${ }^{2}$ We report two cases of $\mathrm{PL}$ in patients following administration of intravenous SVA.

\section{Case Report}

\section{Patient 1}

A 20-year-old male Omani (Arab) was being followed up by us for myoclonic jerks and generalized tonic-clonic seizures since 1990. CT scan brain, blood urea, electrolytes, liver function tests and plasma lactic acid were normal. EEGs done during his previous outpatient visits had shown bifrontal sharp wave and generalised spike discharges. A diagnosis of juvenile myoclonic epilepsy was made. He was being treated with SVA $1600 \mathrm{mg} /$ day and clonazepam $6 \mathrm{mg} /$ day. He was admitted in January 1997 with recent exacerbation of his epilepsy with 3-4 generalized tonic-clonic seizures/day for the previous two days. There was no history of exposure to other neurotoxins. At admission, he was in a post ictal, drowsy state. There were no other neurological deficits. At admission, his free SVA level in the serum was $23 \mu \mathrm{mol} / \mathrm{L}$ (N 15-105). He was treated with an intravenous infusion of SVA $800 \mathrm{mg}(16 / \mathrm{kg}$ body weight) over one hour's time. One hour later, he started laughing uncontrollably. He was conscious but drowsy and could obey simple commands, but could not speak. The laughter was intermittent, spontaneous, unprovoked and could not be suppressed. He had no myoclonus or feelings of mirth during the laughter. SVA free level done at the time of his laughter had risen to $84 \mu \mathrm{mol} / \mathrm{L}$. EEG done at that time showed a background of continuous excessive beta fast activity. There were no epileptiform discharges. A decision was made to omit the subsequent oral dose of SVA and the laughter ceased after 6 hours. Subsequent to this, he was reintroduced on his usual oral dose of SVA and Clonazepam. He did not have any further episodes of abnormal laughter.

\section{Patient 2}

A 17-year-old male Omani patient was being treated for myoclonic and generalised tonic-clonic seizures with $600 \mathrm{mg}$ carbamazepine and $600 \mathrm{mg}$ SVA daily, for 4 years. His mentation and neurological examination were normal. CT scan brain and blood biochemical profile were normal. EEG showed brief generalised bursts of polyspike and sharp discharges lasting less than one second and he was diagnosed to have juvenile myoclonic epilepsy. He was admitted in August 1997 with a cluster of seizures and was treated with an intravenous infusion of $800 \mathrm{mg}$ SVA over one hour. There was no history of exposure to other neurotoxins. One hour later he started laughing uncontrollably which lasted for 4 hours. The laughter was off and on, each episode lasting a few minutes. It was not provoked by stimuli, and was not associated with subjective feelings of mirth. There were no other involuntary movements during the laughter. SVA free level, done at that time was $124 \mu \mathrm{mol} / \mathrm{L}$, and the EEG showed intermittent bifrontal slow waves in the delta range. The subsequent day's dose of SVA was omitted and later he was maintained on $1000 \mathrm{mg}$ of oral sodium valproate daily, without any more episodes of abnormal laughter.

\section{Discussion}

The causes of PL include structural diseases of the brain, seizure manifestation (gelastic), psychiatric illnesses, idiopathic and effect of drugs or toxins ${ }^{3}$ (see Table).

In 1873, Trousseau first described epileptic laughter and Daly and Mulder coined the term "gelastic epilepsy" (gelasmus in Greek = laughter) ${ }^{4}$ Gascon and Lombroso provided the following 5 point criteria for the diagnosis of a gelastic seizure: 1) stereo-typed recurrence; 2) absence of external precipitants; 3 ) concomitance of other ictal manifestations; 4) epileptiform abnormalities on EEG; and 5) absence of other known causes of pathological laughter. ${ }^{4}$ Breningstall, while reviewing patients with gelastic seizures and precocious puberty, suggested that these seizures are due to disturbances in the neuronal pathways connecting the frontal and temporal lobes with the posterior hypothalamus. ${ }^{5}$

From the Department of Medicine (Neurology), College of Medicine, Sultan Qaboos University, Muscat, Oman.

RECEIVED OCTOBER 20, 1997. ACCEPTED IN FINAL FORM MARCH 4, 1998.

Reprint requests to: P.C. Jacob, Lecturer in Neurology, College of Medicine, Sultan Qaboos University, P.O. Box 35, PC 123, Muscat. Oman 
Table: Causes of pathological laughter.

\begin{tabular}{ll}
\hline Structure & Disease \\
\hline 1. Cerebral cortex & $\begin{array}{l}\text { Cerebrovascular disease, } \\
\text { encephalitis, temporal lobe } \\
\text { tumours }\end{array}$ \\
\hline 2. Subcortical white matter & Multiple sclerosis \\
\hline 3. Basal ganglia & Parkinson's disease \\
\hline 4. Hypothalamus & $\begin{array}{l}\text { Hamartomas, gliomas, pituitary } \\
\text { tumours }\end{array}$ \\
\hline 5. Brain stem & $\begin{array}{l}\text { Clival chordoma, brain stem } \\
\text { glioma, posterior fossa tumours }\end{array}$ \\
\hline 6. Pyramidal tracts & Amyotrophic lateral sclerosis \\
\hline 7. Psychiatric causes & $\begin{array}{l}\text { Schizophrenia, personality } \\
\text { disturbances, hysteria, group } \\
\text { hysteria }\end{array}$ \\
\hline
\end{tabular}

8. Psychotropic agents

Phencyclidine hydrochloride, lysergic acid diethylamide, cannabis, methaqualone

9. Toxins Pyrethrins.

Our patients had no overt structural brain lesions or psychiatric disease and the absence of epileptiform discharges in the EEG during laughter ruled out gelastic epilepsy. The temporal profile of PL suggests a causal effect of the intravenous SVA with a rapid rise in the blood and tissue levels (oral doses of SVA have not resulted in PL in the same patients). Since SVA is a GABA agonist it is possible that GABA ergic mechanisms were involved in the production of the PL. In this context it is interesting to note that a disorder of the beta 3 subunit of GABA A receptor due to a chromosomal deletion at 15q11-q13 (Angelman's syndrome) is characterised by easily evoked laughter in addition to severe mental retardation, seizures and ataxia. ${ }^{6}$

Adverse effects following intravenous administration of SVA include headache, reaction at the injection site, nausea, vomiting, somnolence, dizziness, taste perversion, abdominal pain, diarrhoea, hiccups and tremor. In the multicentre, open label trial designed to study the safety of intravenous SVA, the dose used ranged from 0.8 to $37.5 \mathrm{mg} / \mathrm{kg}$ body weight, and the dose per minute of infusion ranged from 0.8 to $25 \mathrm{mg}$.' The dose we used and the rate of administration fell within this range. In summary, we report the rare occurrence of pathological laughter as a side effect in two patients treated with intravenous sodium valproate.

\section{REFERENCES}

1. Devinsky O, Leppik I, Wilmore LJ, et al. Intravenous Valproate Study Team. Safety of intravenous valproate. Ann Neurol 1995; 38: 670-674.

2. Black DW. Pathological laughter: a review of the literature. J Nerv Ment Dis 1982; 170: 67-71.

3. Zellers GL, Frank M, Daugherly J. Pathological laughter. Ann Emerg Med 1990; 19: 327-329.

4. Gascon GG, Lombroso CT. Epileptic (gelastic) laughter. Epilepsia $1971 ; 12: 63-76$.

5. Breningstall GN. Gelastic seizures, precocious puberty and hypothalamic hamartoma. Neurology 1985; 35: 1180-1183.

6. Saitoh $S$, Nickawa N. The GABA A receptor beta 3 subunit gene (GABRB 3) as a candidate responsible for the central nervous disturbances in Angelman syndrome (AS). Nippon-Rinsho 1993; 51: $2409-24113$. 